\title{
The Sunda Strait tsunami, Indonesia: learning from the similar events in the past
}

\author{
Akhmad Zamroni ${ }^{1 *}$, Fajar Rizki Widiatmoko ${ }^{2}$, Muhammad Abdurrozak Siamasahari ${ }^{3}$ \\ akhmadzamroni@itny.ac.id ${ }^{1}$ \\ Department of Geological Engineering, Institut Teknologi Nasional Yogyakarta, Indonesia ${ }^{1}$ \\ Department of Mining Engineering, Institut Teknologi Adhi Tama Surabaya, Indonesia ${ }^{2}$ \\ Department of Hydrogeology Engineering, Institut Teknologi Bandung, Indonesia ${ }^{3}$
}

\begin{abstract}
The Sunda Strait tsunami in Indonesia that occurred on 22 December 2018, generated in 437 total deaths, 16 missing victims, 14,059 injured, and 33,721 displaced people. The number of casualties from this disaster is due to the government's attention in the natural disaster mitigation field is weak. One of the efforts that must be developed by the government is the researches on disaster mitigation. The Sunda Strait tsunami was caused by the eruption of Anak Krakatau volcano followed by an underwater landslide. This natural disaster has similar characteristics from past natural disasters such as the tsunami at Complex Fjords, Norway (1934) and the tsunami at Stromboli volcano, Italy (2002). This paper is to review similar disasters to the Sunda Strait tsunami with the approaches to the process of disasters occur and the disaster mitigation efforts. The process of the Sunda Strait tsunami was began with the collapse of volcaniclastic material into the caldera as deep as $250 \mathrm{~m}$ in the southwest of the volcano. It produced tsunamis with a runup of up to $13 \mathrm{~m}$ on the coasts adjacent to Sumatra and Java. Some suggested mitigations include; the stakeholders create Quaternary maps of Anak Krakatau volcano with a more detailed scale, and the stakeholders install real-time monitoring. These approaches will be used to be suggested for future research in Indonesia regarding the activities of Anak Krakatau volcano.
\end{abstract}

Keywords: Sunda Strait, tsunami, Anak Krakatau volcano, landslide, mitigation

\section{Introduction}

The Sunda Strait Tsunami that occurred on 22 December 2018 in several coastal areas of Banten and Lampung after the eruption of the Anak Krakatau volcano killed 437 people and seriously affected the lives of several residents in the disaster zones [1]. The height of the tsunami was around 3 meters. Anak Krakatau is a small volcanic island in the Sunda Strait, between Sumatra and Java island. Anak Krakatau appeared after the deadly eruption of Krakatau volcano in 1883. "Anak" originated from the Indonesian language which means child. Since June 2018, Anak Krakatau has occurred small eruptions [2]. Indonesia has a very poor early warning system. Indonesia has only tsunami early warning systems totaling 137 tidal gauges, 238 accelerometer stations, and 170 seismic broadband stations. Those systems can send tsunami warnings, but it is just not able to measure the tsunami scale accurately [3].

The scientific-based policy to create early warning systems in Indonesia is still weak, even though many kinds of research about Anak Krakatau volcano have been published, such as "A geophysical interpretation of the 1883 Krakatau eruption" [4], "Tsunami hazard related to a flank collapse of Anak Krakatau volcano, Sunda Strait, Indonesia" [5], and "Understanding the 2007-2008 eruption of Anak Krakatau volcano by combining remote sensing technique 
and seismic data" [6]. Those researches are expected to support early warning systems in Indonesia in the future.

The process of the Sunda Strait tsunami was due to the eruption of the Anak Krakatau volcano followed by an underwater landslide [3]. It has similar characteristics from past natural disasters such as the tsunami at Complex Fjords, Norway (1934) and the tsunami at Stromboli volcano, Italy (2002). This paper is to review similar disasters to the Sunda Strait tsunami with the approaches to the process of disasters occur and the disaster mitigation efforts. These approaches will be used to be suggested for future research in Indonesia regarding the activities of Anak Krakatau volcano.

\section{Method}

In this research, we attempt to review paper topics that related event of Sunda Strait tsunami. Those similar events are the tsunami at Complex Fjords, Norway (1934) and the tsunami at Stromboli volcano, Italy (2002). We focus on the approaches of the process of disasters occur and the disaster mitigation efforts from those events. From that focus, we will attempt to obtain a deep understanding of the process of Sunda Strait tsunami occur and the suggestion Sunda Strait tsunami mitigation efforts for future research in Indonesia. Figure 1 shows the research flow diagram.

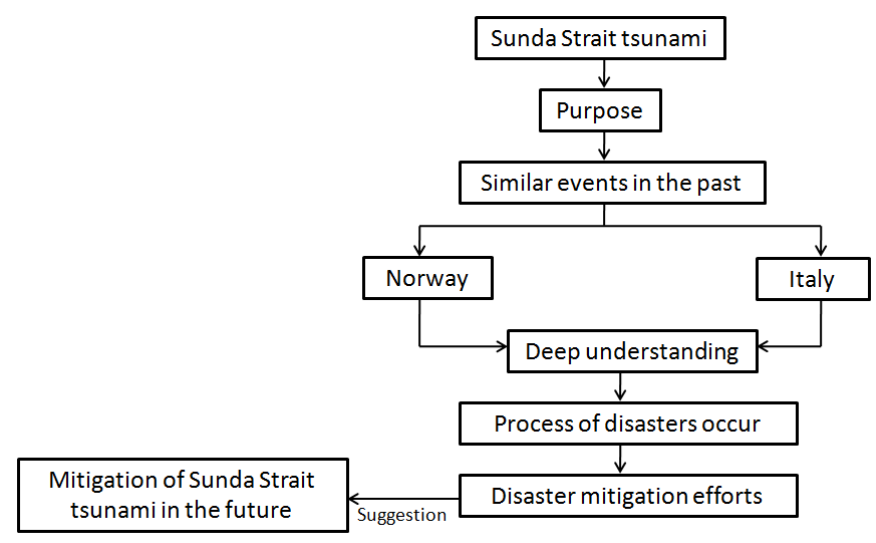

Fig. 1. The research flow diagram

\section{Similar events of the Sunda Strait tsunami}

The unique cause of the Sunda Strait tsunami is due to landslide materials that fall into the sea causing high waves. It was a lateral collapse that began in June 2018. That collapse discharged volcaniclastic materials into the caldera as deep as $250 \mathrm{~m}$ southwest of Anak Krakatau volcano, which produced tsunamis up to $13 \mathrm{~m}$ on its closest coasts on Java and Sumatra [7]. The process of this natural disaster is similar to tsunami at Complex Fjords, Norway and tsunami at Stromboli volcano, Italy.

\subsection{The tsunami at Complex Fjords, Norway}

There are around 3000 people currently living in the tsunami hazard zone around Aknes, Norway's west coast. This number is expected to be higher during the summer due to increasing tourists [8]. Landslides are disasters that have caused major death disasters in Norway. It has been more than 33,000 recorded landslides with 4475 fatalities in Norway. The 
main cause of landslides in Norway was erosion from the glacial mountain cycle [9]. The movement of landslide material into shallow water or seabed has occurred throughout the world with various types of materials such as submarine slides, rock and snow avalanches, slope creeping and cyclic steps, and turbidity currents. Those were caused by tectonic and climatic processes, increased pore, and human activities [10]. Rock avalanches that followed the tsunami are a big danger for communities living in the coastal fjord [11].

In 1934 there was a landslide at Tafjord, a large rock slides of $2-3$ million $\mathrm{m}^{3}$ of scree material and rock mass dropped into the fjord. It produced a tsunami as high as $62 \mathrm{~m}$ above sea level. The number of victims at the event was 41 people and that made the village destroyed, it was followed by 175 people died in three similar events in northern West Norway in the 20th century [12]. The cause of landslides was probably due to unconsolidated breccias that were found in biotite-rich layers. It made weak layers that a role for instability. Before the landslide in 1934, a large block $200 \mathrm{~m}$ wide and $150 \mathrm{~m}$ high $\left(1.5\right.$ million $\left.\mathrm{m}^{3}\right)$ was separated from the stable rock by fractures. The crack increased from a few decimeters to more than 1 meter between 1900 and 1933 until a landslide occurred in 1934. There were 10 large rock-avalanche deposits at the bottom of the fjord through seismic investigations and bathymetrical. Beside, geological mapping showed many slide scars on the slopes above the fjord [13]. In fact, more than $60 \%$ of landslides in the Norway coastal region over the past 175 years can be correlated with rock blasting during construction work on the coastline and the placement of fill [9].

A major rockslide of 0.6-1.9 billion cubic feet (18-54 million cubic meters) may fall into the fjord in the future, it is predicted to produce a tsunami as high as $82 \mathrm{~m}$ above the coastline. The tsunami is expected to strike the Hellesylt community 5 minutes after the landslide [8]. The Geological Survey of Norway has detected 250 unstable rock slopes in Norway. They also carried out activities as part of early-warning systems which include; estimation of the number of potential casualties, assessment of displacement wave propagation and run-up by using physical model tests, run-out assessment based on the volume-dependent angle of reach, and volume estimation [14].

The Geological Survey of Norway (NGU) in collaboration with the Norwegian Water Resources and Energy Directorate (NVE), who is responsible at the government level in Norway creates products that include databases on landslides incidents, country-wide rockfalls, unstable rock slopes, Quaternary maps to characterize potentially unstable deposits, and debris flow maps susceptibility on a scale of 1: 50,000. After quick clay landslides in 1978 at Rissa, Mid Norway, a national program maps out areas where landslides occur due to involving quick clay. Quaternary mapping at a scale on 1: 50,000 by NGU resulted in areas with marine clay-deposits. The mapping uses geotechnical, geomorphological, and topographical criteria. Up to now, the most critical zones have been mapped with regard to quick clay [9].

\subsection{The tsunami at Stromboli volcano, Italy}

Stromboli is a volcano in the Aeolian island arc in the south Tyrrhenian sea, Italy [15]. The height of the Stromboli is between 1700-2200 m, on the north and west flanks bathymetry, and between 1200-1500 m, on the east and south flanks from water depths [16]. Before 30 December 2002, during the last 120 years, six tsunamis have occurred in 1879, 1916, 1919, 1930, 1944, and 1954. On 30 December 2002, a flank collapse in most parts of the Sciara del Fuoco (SDF) triggered a tsunami up to 10 meters above sea level that caused damage to buildings on the east coast of the island. Therefore, the partial collapse of the SDF is the principal source of hazard posed when the volcano eruption. The eruption at Stromboli 
volcano started on 28 December 2002, after a few months prior there was a strong explosive activity at the summit craters. On December 30, two large flank failures and associated tsunami waves were recorded based on the seismic network. Geophysical and volcanology monitoring, and thermal surveys provide information on flank failure, the dynamics of Stromboli's effusive eruptions, and their potential hazards [17].

The tsunami that occurred in the Aeolian Islands in 2002 was caused by mass movements (either landslides or hot avalanches). The role of the earthquake is a too small influence for the dislocation of the seafloor that moves the submarine mass. Some estimates of the tsunami process in Stromboli in 2002 are similar to previous events; (1) underwater landslides in the SDF, causing the sea to retreat first and triggering greater damage on the northern Stromboli coast, similar to the 1916 tsunami, (2) the eruptive column collapse to the submarine, similar to the 1919 tsunami, (3) a submarine failure of SDF and the hot avalanche down to the northern flank of the volcano, similar to the 1930 tsunami, (4) the hot avalanche on the southwestern flank of Stromboli, similar to the 1944 tsunami, and (5) a submarine failure in the southeastern flank of Stromboli, similar to the 1954 tsunami [18]. In 2003, in anticipation of victims of the Stromboli eruption, the government undertook several disaster mitigations including; (1) new geochemical and geophysical volcano surveillance networks, and (2) real-time monitoring, where signals from volcano monitoring are visualized in realtime and following used by the personnel of the Department of Civil Protection (DPC) to immediately activate the response procedure, then the DPC must coordinate information with the media and the surrounding population. Information is disseminated through scientific websites, public meetings held with local residents, DPC websites, and interviews by scientists and DPC personnel to the media. The purposes of handling media directly by the DPC are to guarantee the provision of reliable information to the media, reducing the pressure on busy scientific personnel, and minimizing the potential for exaggeration news [19].

\section{Learning from the similar natural disasters in the past}

Tsunamis that result from submarine landslides occur through the energy that is transferred from landslides to water motion. The characteristics of tsunamis caused by landslides depend on water depth, sliding volume and dynamics, initial acceleration and maximum velocity of landslides, and friction at the material interface of landslides and water [20]. Avalanches with rock material falling into the sea or lake can trigger tsunamis, with wave heights of hundreds of meters. Although landslides with rock materials are less common than other materials (e.g. debris flows, rock falls), they have a high potential for danger. Therefore, it is essential to characterize mountain fronts where rock avalanches can occur and to understand their recurrence times [13].

The process of the Sunda Strait tsunami was began with the collapse of volcaniclastic material into the caldera as deep as $250 \mathrm{~m}$ in the southwest of the volcano. It produced tsunamis with a runup of up to $13 \mathrm{~m}$ on the coasts adjacent to Sumatra and Java. The estimated collapse of submarine materials results in a range of primary landslide volumes of $0.22-0.30$ $\mathrm{km}^{3}$ with the speed of the tsunami reaching the nearest coastline in about 30 minutes. There were no early warning signals in this disaster and because of the short travel time of the tsunami, it made a big challenge to reduce the impact of the tsunami in the coastal areas [7]. The similarity of the Sunda Strait tsunami with the tsunami at Complex Fjords, Norway and the tsunami at Stromboli volcano, Italy is a tsunami caused by material falling into the depths of water to produce high waves. From this similarity, we can propose to find out the points of the Anak Krakatau volcano that contain weak material from landslides (e.g. clay minerals or unconsolidated materials) and study the parts of the Anak krakatau volcano to prepare early 
warning if occur underwater landslides, the eruptive column collapse, a submarine failure, and the hot avalanche collapse.

After we know the process of the disaster occurrence, we can adapt the disaster mitigations that have been done in the tsunami at Complex Fjords, Norway and the tsunami at Stromboli volcano, Italy to be applied in the Sunda Strait tsunami. Some suggested mitigations include; the stakeholders create Quaternary maps of Anak Krakatau volcano with a more detailed scale to characterize potentially unstable deposits and debris flow maps susceptibility, and the stakeholders installing real-time monitoring, where signals from volcano monitoring are visualized in real-time and following used by the stakeholders to immediately activate the response procedure. Figure 2 shows the diagram of research result.

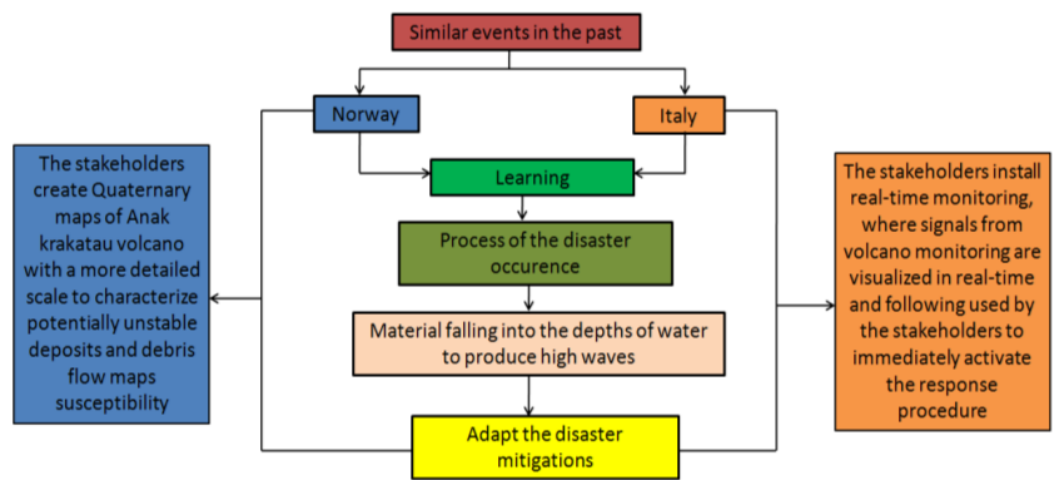

Fig. 2. The diagram of research result

\section{Conclusion}

The similarity of the Sunda Strait tsunami with the tsunami at Complex Fjords, Norway and the tsunami at Stromboli volcano, Italy is a tsunami caused by material falling into the depths of water to produce high waves. The process of the Sunda Strait tsunami was began with the collapse of volcaniclastic material into the caldera as deep as $250 \mathrm{~m}$ in the southwest of the volcano. It produced tsunamis with a runup of up to $13 \mathrm{~m}$ on the coasts adjacent to Sumatra and Java. We can adapt the disaster mitigations that have been done in the tsunami at Complex Fjords, Norway and the tsunami at Stromboli volcano, Italy to be applied in the Sunda Strait tsunami. Some suggested mitigations include; the stakeholders create Quaternary maps of Anak Krakatau volcano with a more detailed scale, and the stakeholders install realtime monitoring, where signals from volcano monitoring are visualized in real-time and following used by the stakeholders to immediately activate the response procedure.

\section{Acknowledgment}

We thank you to Institut Teknologi Nasional Yogyakarta for providing support to write this paper. Thanks also for Ayu Atikha Reinaty, my beloved wife that helped us especially in terms of writing techniques. 


\section{References}

[1] Tempo. 2019. Sunda Strait Tsunami Victims; 437 Died, 9 Unidentified. <https://en.tempo.co/read/1160432/sunda-strait-tsunami-victims-437-died-9unidentified>. Accessed on September 6, 2019.

[2] Heriyanto D. 2018. Sunda Strait tsunami: What we know so far. <https://www.thejakartapost.com/news/2018/12/23/sunda-strait-tsunami-what-weknow-so-far.html>. Accessed on September 6, 2019.

[3] BBC. 2018. Indonesia earthquake and tsunami: How warning system failed the victims. <https://www.bbc.com/news/world-asia-46663158>. Accessed on September 6, 2019.

[4] Yokoyama I. A geophysical interpretation of the 1883 Krakatau eruption. Journal of Volcanology and Geothermal Research. 1981 Mar 1;9(4):359-78.

[5] Giachetti T, Paris R, Kelfoun K, Ontowirjo B. Tsunami hazard related to a flank collapse of Anak Krakatau volcano, Sunda Strait, Indonesia. Geological Society, London, Special Publications. 2012 Jan 1;361(1):79-90.

[6] Agustan, Kimata F, Pamitro YE, Abidin HZ. Understanding the 2007-2008 eruption of Anak Krakatau Volcano by combining remote sensing technique and seismic data. International Journal of Applied Earth Observation and Geoinformation. 2012 Feb $1 ; 14(1): 73-82$.

[7] Grilli ST, Tappin DR, Carey S, Watt SF, Ward SN, Grilli AR, Engwell SL, Zhang C, Kirby JT, Schambach L, Muin M. Modelling of the tsunami from the December 22, 2018 lateral collapse of Anak Krakatau volcano in the Sunda Straits, Indonesia. Scientific reports. 2019;9.

[8] Rød SK, Botan C, Holen A. Risk communication and worried publics in an imminent rockslide and tsunami situation. Journal of Risk Research. 2012 Jun 1;15(6):645-54.

[9] Hermanns RL, Hansen L, Sletten K, Böhme M, Bunkholt H, Dehls JF, Eilertsen R, Fischer L, LHeureux JS, Høgaas F, Nordahl B. Systematic geological mapping for landslide understanding in the Norwegian context. Landslide and engineered slopes: protecting society through improved understanding. Taylor \& Francis Group, London. 2012:265-71.

[10] Bellwald B, Hjelstuen BO, Sejrup HP, Haflidason H. Postglacial mass movements and depositional environments in a high-latitude fjord system-Hardangerfjorden, Western Norway. Marine Geology. 2016 Sep 1;379:157-75.

[11] Løvholt F, Glimsdal S, Lynett P, Pedersen GK. Simulating tsunami propagation in fjords with long-wave models. Natural hazards and earth system sciences. 2015;15(3):657-69.

[12] Kveldsvik V, Eiken T, Ganerød GV, Grøneng G, Ragvin N. Evaluation of movement data and ground conditions for the Åknes rock slide. InInternational Symposium on Stability of Rock Slopes in Open Pit Mining and Civil Engineering Situations 2006 Apr (Vol. 3, pp. 279-299).

[13] Hermanns RL, Blikra LH, Naumann M, Nilsen B, Panthi KK, Stromeyer D, Longva O. Examples of multiple rock-slope collapses from Köfels (Ötz valley, Austria) and western Norway. Engineering Geology. 2006 Feb 28;83(1-3):94-108.

[14] Oppikofer T, Hermanns RL, Sandøy G, Böhme M, Jaboyedoff M, Horton P, Roberts NJ, Fuchs H. Quantification of casualties from potential rock-slope failures in Norway. Landslides and Engineered Slopes: Experience, Theory and Practice. 2016 Jun:153744.

[15] Tinti S, Pagnoni G, Zaniboni F, Bortolucci E. Tsunami generation in Stromboli island and impact on the south-east Tyrrhenian coasts. Natural Hazards and Earth System 
Science. 2003;3(5):299-309.

[16] Tinti S, Bortolucci E, Romagnoli C. Computer simulations of tsunamis due to sector collapse at Stromboli, Italy. Journal of Volcanology and Geothermal Research. 2000 Feb 1;96(1-2):103-28.

[17] Bonaccorso A, Calvari S, Garfì G, Lodato L, Patanè D. Dynamics of the December 2002 flank failure and tsunami at Stromboli volcano inferred by volcanological and geophysical observations. Geophysical Research Letters. 2003 Sep;30(18).

[18] Maramai A, Graziani L, Tinti S. Tsunamis in the Aeolian Islands (southern Italy): a review. Marine Geology. 2005 Feb 28;215(1-2):11-21.

[19] Bertolaso G, De Bernardinis B, Bosi V, Cardaci C, Ciolli S, Colozza R, Cristiani C, Mangione D, Ricciardi A, Rosi M, Scalzo A. Civil protection preparedness and response to the 2007 eruptive crisis of Stromboli volcano, Italy. Journal of Volcanology and Geothermal Research. 2009 May 10;182(3-4):269-77.

[20] Harbitz CB, Glimsdal S, Løvholt F, Kveldsvik V, Pedersen GK, Jensen A. Rockslide tsunamis in complex fjords: from an unstable rock slope at Åkerneset to tsunami risk in western Norway. Coastal engineering. 2014 Jun 1;88:101-22. 